\title{
STRUCTURAL CHANGES OF CAPSULAR, VASCULAR, GLIAL AND NEURAL ELEMENTS OF THE SPINAL GANGLIA IN ACUTE EXPERIMENTAL EDEMA. LIGHT AND ELECTRON MICROSCOPIC STUDIES
}

\author{
E.K.Gasimov*, A.A.Aliyarbayova \\ Azerbaijan Medical University, Department of Histology, cytology and embryology, Baku
}

Keywords: spinal ganglia, acute endotoxemia, degenerative d
Introduction: The participation of pseudouni-
polar neurons (the main component of spinal
ganglia) in the synthesis of cytokines (Tumor
Necrosis Factor alpha - TNF $\alpha$, prostaglandin
E2 and prostacyclin) from the impact of E.coli
endotoxin as ligand of Toll Like Reseptor 4
(TLR4), which cause to neuropathic and inflam-
matory pains was studied in detail [Tse K.H. et
al. 2014; Chow K.B. et al., 2014]. During the
alteration in pseudounipolar cell as a result of
the impact of endotoxin attracts attention the
essential role of non-neural elements (macro-
phage, satellite glial and endothelial cells) in the
composition of spinal ganglia [Li Y. et al., 2004].

The communication between neurons and satellite glial cells in spinal ganglia were investigated ultrastructurally [Pannese E., 2010; Hanani M., 2012; Ng K.Y. et al., 2013; Gasimov E.K., Aliyarbayova A.A., 2014], in toxic injury [Tomiwa K. et al., 1986; Ramesh G. et al., 2013; Blum E. et al., 2014], in axotomy of sciatic nerve [McKay Hart A. et al., 2002; Atlasi M.A. et al., 2009; Momeni H.R. et al., 2013] at the appropriate level. However, with disagreements between acquired information, the change in membranevascular-glial-neural elements in spinal ganglia during inflammatory process that developed at acute endotoxemia described is insufficiently. On the other hand, the influence of endotoxin to pseudounipolar cell cultures has been studied mostly in vitro conditions. The main reason of the current research is to investigate changes in histotopography and structure of neural and non-neural elements of spinal ganglia after 2 hours injection into veins of E.coli endotoxin in vivo conditions at light and electron microscopic level.

Material and methods. The objects of research are 20 white rats with weight of 200-220 gr maintained under standard laboratory conditions approved by the Azerbaijan Medical University were divided into 2 groups: control and experimental. The experimental edema model was created through injection of $0.5 \mathrm{ml}$ physiological salt solution into the tail vein of animals in control group and injection of $0.5 \mathrm{ml}$ E.coli lipopolysaccharide (LPS) (Serotip 0111:B4 InvivoGen, San Diego, CA 92121) in physiological salt solution with dosage of $1 \mathrm{mg} / \mathrm{kg}$ to the same vein of animals in experimental group. 2 hours after intravenous injection animals were decapitated under ketamine anesthesia; the abdominal and thoracic cavity of the rat was opened, then was taken out the internal organs and the vertebral bodies were cut. Later by the help of special lancet, a spinal canal opened and spinal ganglions were removed from the soft tissue in intervertebral foramen level. Via this method spinal ganglia damage is minimum. The spinal ganglia had been fixated in solution that contains $2 \%$ paraformaldehyde, $2 \%$ glutaraldehyde and $0.1 \%$ picrin acid prepared in phosphate buffer ( $\mathrm{pH}$ 7.4). After the postfixation in $1 \%$ osmium acid solution during 2 hours in phosphate buffer, the specimen prepared in Spurr and Araldit-Epon blocks according to general methods accepted in electron microscopy (John Kuo, 2007). Obtained from blocks on LKB -III, Leica EM UC7 ultratomes semithin sections $(1-2 \mu \mathrm{m})$ were stained with methylene blue, azure II and basic fuchsine or with toluidine blue, after examination with Latimet (Leitz) microscope necessary parts of images were taken by Pixera (USA) digital camera. Silver and gold ultrathin sections from same

* e-mail: geldar1949@gmail.com 
blocks first painted with $2 \%$ uranyl acetate solution, then in $0.6 \%$ lead citrate made in $\mathrm{NaOH}$ $0.1 \mathrm{~N}$ solution. After examination of ultrathin sections under $80-120 \mathrm{kV}$ in transmission electron microscope JEM-1400 were taken electronograms.

The obtained results and their discussion. The research results show that the first symptom during acute experimental endotoxemia created by intravenous injected LPS is collection of edema in subcapsular, perivascular, perineuronal and interneuronal parts of spinal ganglia caused by the sharp increase in the permeability of blood vessels.

As the occurrence of edema at endotoxemia cause to acute increase of intraorganic hydrostatic pressure, the structural elements of spinal ganglia are subjected to mechanical impact in this or more less degree. First of all was subjected to mechanical injury the capsule of spinal ganglia that composed of outer irregular connective tissues elements and inner specialized containing from several perineural cells layer. As shown in fig. 1A, derivations having role in the composition of spinal ganglion are surrounded with capsule relatively light in outer, but dark painted within interior and having overall continuous structure. During the experimental edema (fig.1B) the part composed from perineural cells of spinal ganglion capsule remained relatively unchanged in right upper part of semithin section (shown with one arrows), while the violation of capsule's inner part integrity is clearly visible in other part of microphotography. "Perineural window" arised during the violation of structural elements of capsule are shown with two arrows. As the result of oedematous fluid pressure at described part of spinal ganglion capsule that consisting of external connective tissue elements where its integrity is violated, we can see separate fragments in transverse section. However, in bottom of left part of microphotography show in fig. $1 \mathrm{~B}$, the capsule elements in the result of accumulation liquid pressure in subcapsular space are not visible because they are moved away for $50 \mu \mathrm{m}$ from the place housed of neural cells.
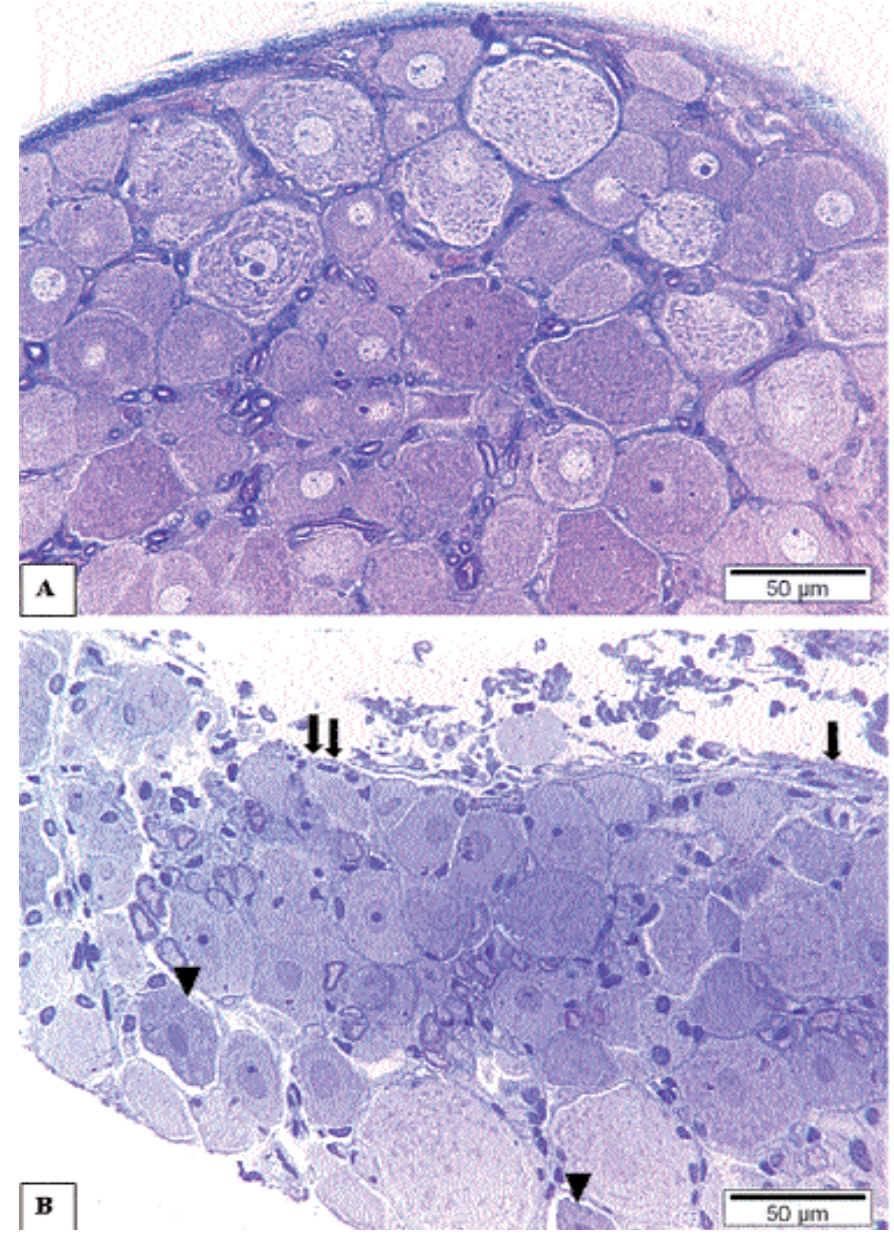

Fig. 1. The comparative descriptions of spinal ganglion structural elements in control group $(A)$ and during experimental edema (B). The explanation is given in text. Microphotography. Semithin sections, toluidine blue dye. Scale bars: $A, B 50 \mu \mathrm{m}$.
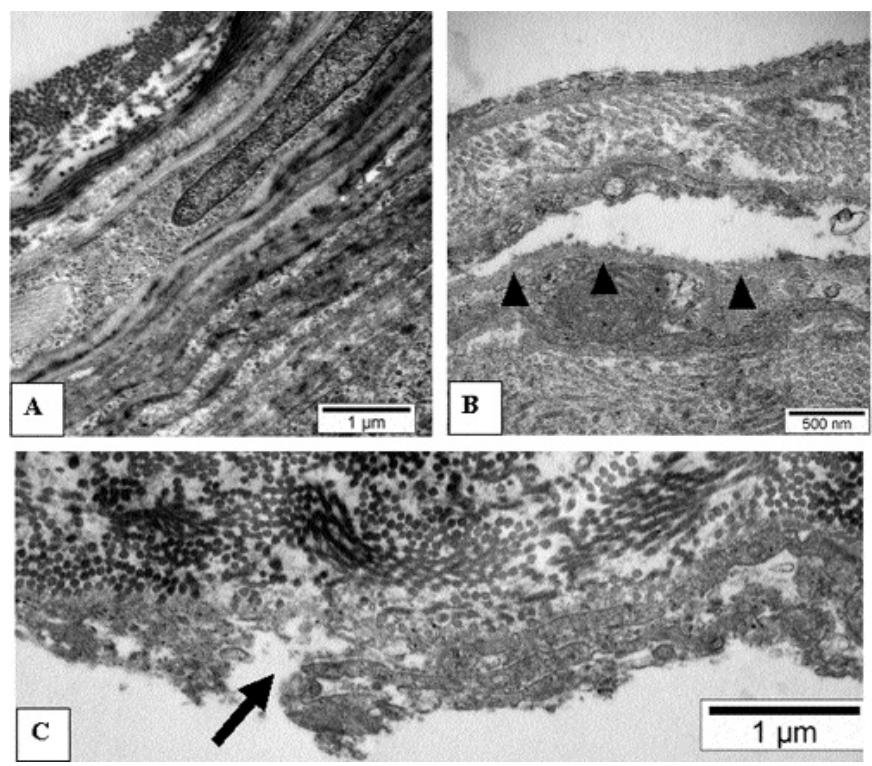

Fig. 2. The interior layer of spinal ganglion capsule consisting of perineural cells in control group $(A)$ and during acute endotoxemia $(B, C)$. The explanation is given in text. Electron diffractions. Scale bars: A, C 1 $1 \mu \mathrm{m}, B 500 \mathrm{~nm}$. 
The changes in cellular and fibrillar derivations taking part in the composition of spinal ganglion capsule compared with control group are given in ultrastructural level in fig.2. As shown, the internal layer of spinal ganglion capsule is composed of flattened perineural cell that both sides surrounded with basal lamina and between them located collagen fibers according to their diameters belong to III group. At experimental endotoxemia occur completely different from each other on electron microscopic appearance alterations but in results with violation of integrity of perineural cell layer. As seen from fig.2B in the result of edematous fluid pressure a perineural cell layer getting away from basal lamina covering it from inside (shown with arrow head), but its integrity is completely violated in right bottom. Therefore, in the upper part of the picture is visible a basal lamina, covering from inside of perineural cell layer in comparison with control group does not alter violation of integrity, but plasmalemma covering cell from outside is partially and basal lamina are completely invisible. In fig. $2 \mathrm{C}$ shown the edematous fluid caused to fragmentation of perineural cell and to formation of microscopic "perineural window" (shown with arrow) with measure of $400 \mathrm{~nm}$.

The first fact attracting the attention during the electron microscopic research of internal vessels of spinal ganglia was the shrinking of vessels included into the content of microciculatory vascular network as a result of pressure edematous fluid. In electron diffraction presented in fig. 3A the existence of deformated smooth muscle cells in periendothelial space proves that the described microvascular vessel is precapillary arteriol. Even though the thickness of wall precapillary arteriole in comparison with size of lumen was large, so during endotoxemia the deformation of it caused to hypoxia structural components of spinal ganglia. One the reasons of narrowing of intraganglionic capillary is getting tumescent due collected edema liquid in cytoplasms of endothelilal cell having role in composition of their wall (fig. 3B). On one hand the collected edema liquid at cytoplasm of endothelial cell cause to the decrease of electronic density; on the other hand cause narrowing of capillary lumen due their increased volume. In given parts, formed blood elements by closing vascular lumen created blockages with violation of the blood flow. On the contrary to descriptions, in postcapillary venule's walls are revealed the dark endotheliocytes (E2) formed due dehydratation by increasing density of cytoplasm elements (fig. 3D). The each other replacement of different type finger-shaped protrusion, wide and thinned parts of cytoplasms on luminal surfaces of these cells indicates that they are subjected to acute contraction during formation of dark endotheliocytes. The violation integrity of basal lamina around the described thinned parts shows the increase of selective permeability of endothelial cells as in the amount that cause to revealing of interganglionic oedema (shown with asterisk) at that part. In some cases, the violation of junction between endothelial cell causes to formation opened paracellular pathway for edematous fluid to entrance into perivascular space.

During acute endotoxemia, at the same time with reactive changes in endothelial cells (the collection of oedema liquid without violating the completeness of cell membrane, the occurrence of various shaped and size pseudopodia on luminal surfaces, the increase of free and connected pinocytotic vesicles, etc.) of interganglionic vessels of spinal ganglia are observed also the increase of free and polyribosomes, considered as indicators of increased synthetic activity in their cytoplasms, necrotic changes due to partial or complete violation (shown with arrow in fig. 3C) of cell membrane.

The interesting fact is that, there are different changes both in vascular surface and in cytoplasms of endothelial cells having role in the composition of same vascular wall. The increased number of ribosomes and pinocytotic vesicles in endothelial cell of postcapillary venule marked with $\mathrm{E} 1$, the dark endotheliocyte subjected to degenerative changes shown in upper part in E2, the endotheliocyte swollen due to collected edema liquid in its cytoplasm in E3 are clearly visible in fig. 3D. 


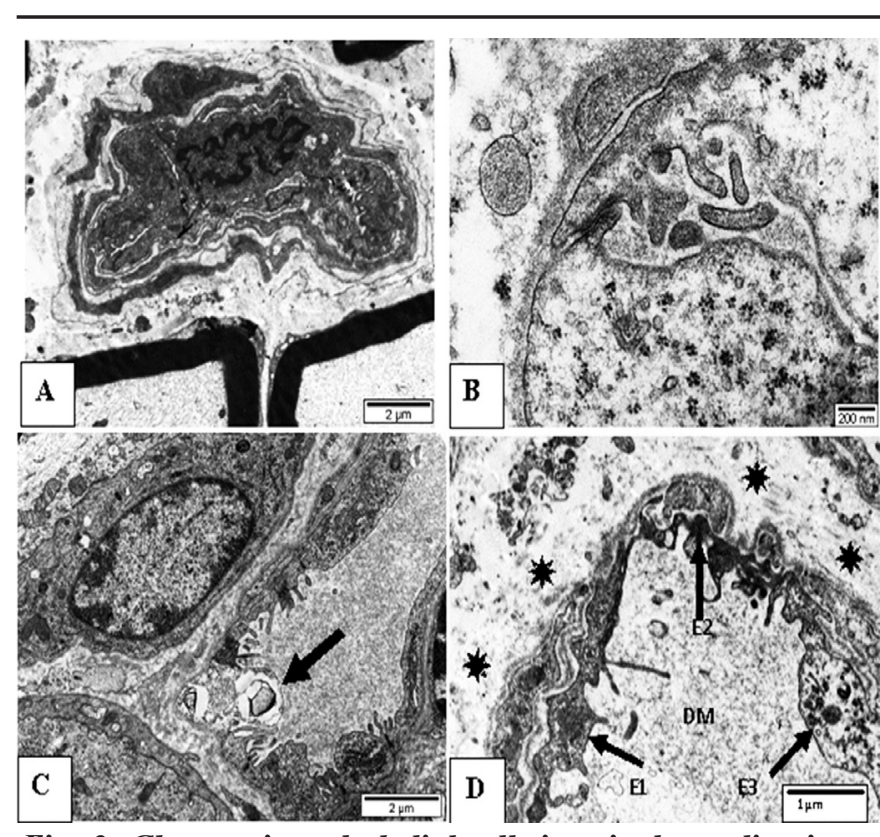

Fig. 3. Changes in endothelial cells in spinal ganglion internal vessels during acute endotoxemia. The explanation is given in the text. Electron diffractions. Scale bars: $A, C$ $2 \mu \mathrm{m}, \mathrm{B} 200 \mathrm{~nm}, \mathrm{D} 1 \mu \mathrm{m}$.

The reveal of macrophages characterized with violation of plasmalemmas together with increased elements of phagocytic activity is attracting attention around perivascular parts of spinal ganglion (fig. 4A). At acute endotoxemia observing some facts (shown in fig. 4) given the opinion that mononuclear phagocytes have significant role in occurrence of different changes in spinal ganglion: on the upper part from demonstrated macrophage the endothelial cell decreased electronic density due collection of edema liquid; the widened space between satellite and neuronal cells in left bottom (shown with asterisk); the dark degenerative neuron (see next) without glia coverage due the impact of oedematous liquid. In zoomed part of discussed picture, the violation of plasmalemma integrity that should surround the cytoplasmic elements of macrophage is clearly visible, while there is no alteration in neuron subjected to degenerative changes (in left bottom) and satellite glial cell membranes, the basal lamina that should be around of last and in structure of cytoplasmic elements of macrophage. The descriptions show that, during acute endotoxemia the macrophages in spinal ganglion is subjected to pyroptosis considered as programmed cell death forms [Fink S.L.,Cookson B.T., 2007] (see next).

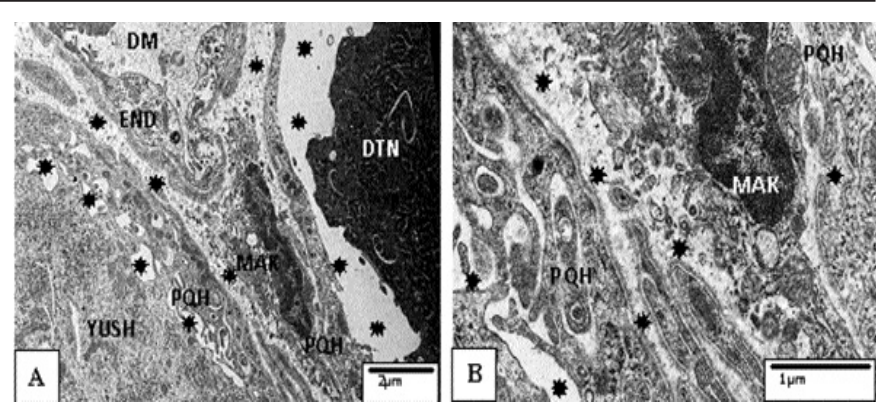

Fig. 4. Changes in neuro glial connections $(A)$ and perivascular macrophages $(B)$ in spinal ganglion internal vessels during acute endotoxemia. The explanation is given in the text. Electron diffraction. Scale bars: A $2 \mu \mathrm{m}, \boldsymbol{B} 1 \mu \mathrm{m}$.

The dark and light neurons are found in spinal ganglion [Pannese E., 2010; Hanani M., 2012; Gasimov E.K., Aliyarbayova A.A., 2013] according to dense and loose arrangement of organelles, cytoskeletal elements. In the present study, alongside with dark neurons subjected to reactive changes under the influence of endotoxin (see the next), has the dark neurons those recovery is impossible. Considering this, we will call the first ones as dark, and the second ones as dark degenerative neurons (DDN).

The changes in neuron-glial connections in spinal ganglia during acute endotoxemia are clearly visible under average magnification (x500) of light microscope. As it shown from fig. 1B, while edema fluid housed inside of connective tissues elements that separate spinal ganglion neurons from covering glia, detected slit-shaped unpainted space (in left bottom of microphoto), so the identification borders of glial cells covering neurons, which compressed due to the pressure of edema liquid is becoming quite difficult under 500 (in central and left parts of fig. 1B), even in 1000 (in central part of fig. 6A) times magnification. The nucleus of pseudounipolar cell in control group having circular form and painted light with toluidine blue (chromophobe), but during acute endotoxemia they are painted dark as being subjected to various deformations (fig. 1B). There is not any problem in differentiation of light and dark neurons on size of diameters in control group, however, during endotoxemia medium and small pseudounipolar cell get painting homogenous nature (fig. 1B and 6A). In the pictures with reference to those described, it is the dark paintings of cytoplasmic elements including the 
nucleus of neurons subjected to degenerative changes indicated with arrowhead (see the next).

During endotoxemia in vast majority of both dark (fig. 5B) and light (fig. 5D) neurons on ultrastructure, in comparison with control group (respectively fig. 5A and 5C) there is chromatolysis (tigrolysis) characterized with expansion cisterns of granular endoplasmic reticulum and ribosomes around them to became free. As shown in fig. 5D in ultrathin section of light neuron from many ribosomes maximum 10 seen on the cisterns of endoplasmic reticulum, while in control group does not have endoplasmic reticulum cisterns that lost its connection with ribosomes (fig. 5C). At the same time with above shown, sometimes there are different sized unpainted parts in cytoplasm due partially (is shown with arrow in fig. 5D) or complete loss of membranes surrounding cisterns of rough endoplasmic reticulum.
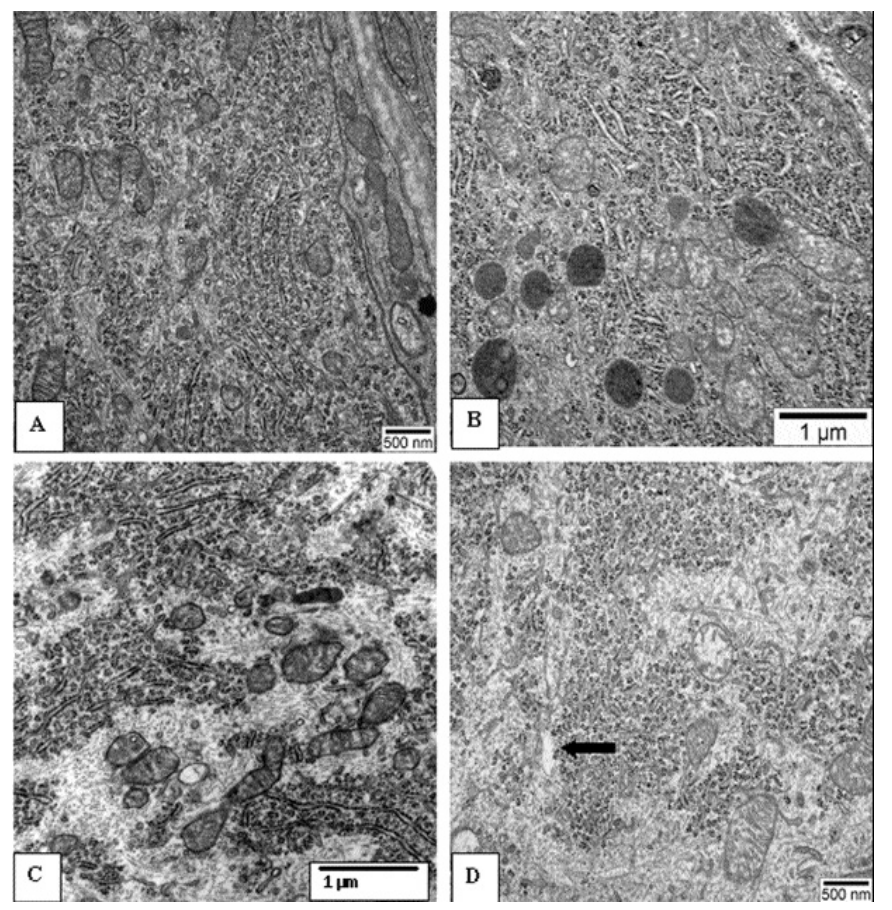

Fig. 5. Spinal ganglion organelles and cytoskeletal elements in control group $(A, C)$ and during acute endotoxemia $(B, D)$. The explanation is given in text. Electron diffraction. Scale bars: A, D $1 \mu \mathrm{m}, B, C 500 \mathrm{~nm}$.

During endotoxemia, observed the increase in number of mitochondria, lysosome and peroxisomes in pseudounipolar neurons of spinal ganglion (fig. 5B), the tumescence of the first and various type deformations of crists. Notwithstanding the increase of neurofilaments taking part in the composition of cytoskeleton elements of neuron, the vision impossibility (fig. 5B and 5D) of their borders under 80000 time magnification in comparison with control group (fig. 5A and 5C) due result of absorption of oedema liquid draws attention.

Reactive changes above described in both dark and light neurons in studied experimental oedema model, cause to formation in some pseudounipolar neurons the dark degenerative neurons with destructive feature (shown with arrow in fig. 1B and 6A). Even are clearly visible the unpainted slit-shaped space filled with oedema fluid, among the pseudounipolar neurons that subjected to acute dehydration and coagulation of cytoplasmic elements and their glial covers under average magnification of light microscopes (shown with little asterisks in fig. 6A). Sometimes it is impossible to identify the violation of connection between dark degenerated neurons and glia cells on light microscope. During electron microscopic study of those parts (fig. 6B) draws attention, while not any significant changes in structure of plasma membrane on side basal lamina of the satellite glial cell with expanded granular endoplasmic reticulum, but observed violation of integrity of plasmalemma of the satellite glial cells covering part to pseudouniplar neurons and visible separation of described cells by oedematous fluid. From the early periods of formation dark degenerative neurons, the darkening of structures that are part of cytoplasm and nucleus continue in paralel due condensation (fig. 6B). In intermediate stages of this process (fig. 6C) it is possible to notice the changed profiles of lysosome, some mitochondria and Nissl substance in cytoplasm of pseudouniplar neurons spinal ganglia. Nevertheless, on final stages of degeneration are not noticed the structures of organelles and cytoskeletal elements, besides different shaped expansions not surrounded with plasma membrane inside cytoplasm with homogenous granular mass (fig. 6D). 


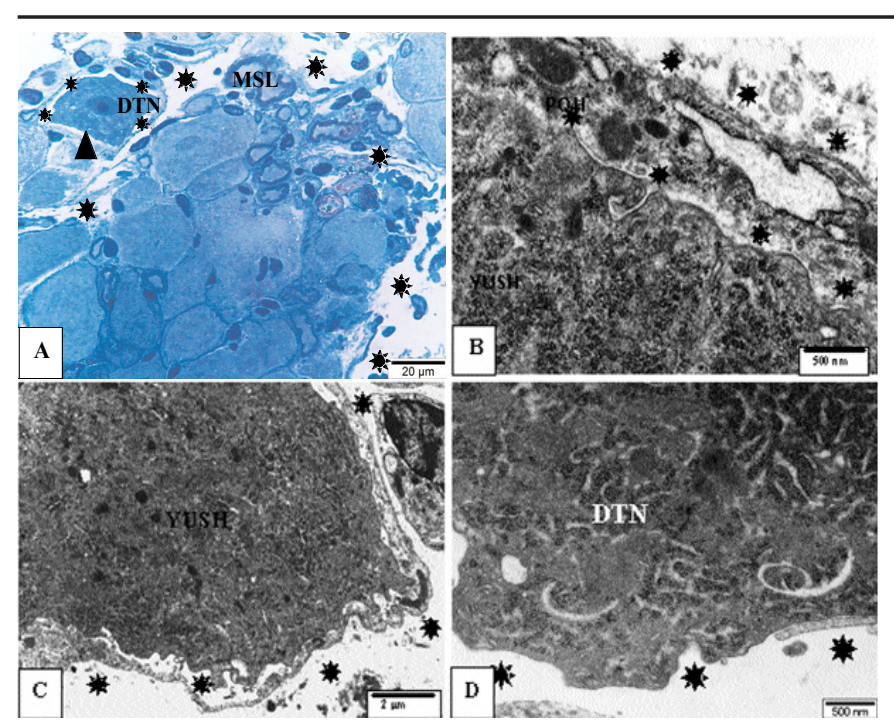

Fig. 6. Light $(A)$ and electron microscopic $(B, C, D)$ pictures of $D D N$. The explanation is given in text. Scale bars: A $20 \mu \mathrm{m}, B, D 500 \mathrm{~nm}, C 2 \mu \mathrm{m}$.

During the acute endotoxemia, the formation of edema liquid due the increase of intraorganic vascular permeability has great importance in both mechanical and structural changes in spinal ganglion. According to its topographic condition, the endothelial cells composing inner layers of spinal ganglion vessels and expressed in luminal surfaces TLR4, are first subjected to injury of endotoxin E.coli injected to the vein. It should be noticed cause to formation of intraganglionic oedema due increasing of vascular permeability of spinal ganglion vessels, as in other organs [Roger T. et al., 2003; Chuang Y.C. et al., 2011], that secretion prostaglandin E2, prostacyclin I2 by endothelial cell [Prins B.A. et al., 1994] and pseudounipolar neurons, releasing macrophage migration inhibitory factor (MIF) [Tse K.H. et al., 2014], especially from activated macrophage in spinal ganglia.

Along with "perineural windows" surrounding great part field of view on small magnification of light microscope, formed in spinal ganglion capsule due the impact of oedema liquid, the various deformation of vascular, glial, neural elements give grounds that the described oedema liquid is high in weight measure. During acute endotoxemia was observed [Gasimov E.K. et al., 2010] formation of "perineural windows" in nerve fibers with diameters of 400-600 $\mu \mathrm{m}$ taking part in the composition of peripheral nerves, but their measures are significantly little in comparison with spinal ganglion capsule. The analysis of received materials shows that, it is possible to explain the reason of big measures of perineural windows formed during acute endotoxemia in spinal ganglion capsule by the help of three facts:

- as the diameter of the biggest group in the composition of peripheral nerve bundles is not more than $600 \mu \mathrm{m}$, in spinal ganglion this indicator is at least two times higher;

- the total number of vessels within spinal ganglia greater at least 4 times than the number of blood vessels housed in the relevant areas of nerve bundles. While the perimeter of vessels (the size of exchange surface) is at least 1.8 higher than the perimeter of spinal ganglion capsule, the same index in peripheral nerve bundles is lower two times;

- The amount of dense formed connective tissue elements located around last layer of perineural cell surrounding nerve fibers and protecting it from mechanical effects is three times thick in comparison with external layer of spinal ganglion capsule.

As the infiltration of neutrophils in lower doses of endotoxin within spinal ganglion is not noticed like in central nervous system, the nonspecific cellular defence that is part of the innate immunity is carried out mainly by macrophages. The received nuclear signals in the result of LPS-TLR 4 connection activating nuclear factor kappa B (NF-kappaB), as other nucleus cells [Medzhitov R. and Janeway C., Jr. 2000], chemokines having chemotaxis impact and having role in the activating of macrophages are synthesized along with pre-inflammatory cytokines by endothelial cells [Fujihara M. et al., 2003; Kang S. et al., 2009]. It is not coincidence that, unlike the experimental drugs, during acute endotoxemia macrophages with different changes is found around approximately all of internal vessels of spinal ganglion. The fact most drawing attention among changes is the mortality of macrophages via pyroptosis observed with the violation of plasmalemmas' integrity, unlike there is no any structural changes in great majority of other cytoplasmic 
elements due expansion of perinuclear space and increase of heterochromatin in nucleus (fig. 4B). It should be noticed that, the first information on pyroptosis mortality of cells was published in the "Pre-inflammatory programmed death" article of professor B.T.Cookson of the Washington University, USA in 2001. Considering that, the replication of bacteries [Fink S.L., Cookson B.T., 2007] are going in cytoplasm of macrophage [Miao E.A. et al., 2011], they accept pyroptosis like cleaning method of organism from cytoplasmic pathogens [Aachoui $Y$ et al., 2013] as integral part of innate immune. On other hand, they include it to the programmed cell death forms as apoptosis due DNA fragmentation during pyroptosis [Qu Y et al., 2012]. However, different form apoptosis, the pyroptosis happens with the participation of caspase- 1 and caspase-11 enzymes, not with proteolytic enzymes as caspase- 3 and caspase-8. Therefore, in the formation of pyroptosis participated the cytoplasmic protein complex named inflammasome. In the result of the impact of pathogen signal, the inactive procaspase- 1 and procaspase- 11 in the composition of inflammasome getting active turn into caspase- 1 and caspase-11. The last ones subjecting the cell membrane into lysis cause to macrophages' death. [Fink SL, Cookson BT, 2007; Aachoui $Y$ et al., 2013]. In their turn, pathogen substances in intercellular space, eliminating by phagocytosing via different methods, also mainly by neutrophils prevent the development inflammatory process in organism.

The peculiarity of presented study work is that, not the E.coli considered as gram negative bacteria itself but the LPS having role in composition of their walls are injected into veins.

\section{REFERENCES}

1. Aachoui Y., Sagulenko V., Miao E.A., Stacey K.J. Inflammasome-mediated pyroptotic and apoptotic cell death, and defense against infection // Curr Opin Microbiol. , 2013, 16(3), pp.319-26.

2. Atlasi M.A., Mehdizadeh M., Bahadori M.H., Joghataei M.T. Morphological Identification of Cell Death in Dorsal Root Ganglion Neurons Following Peripheral Nerve Injury and Repair in Adult Rat // Iranian Biomedical Journal, 2009, 13 (2), pp. 65-72

3. Blum E., Procacci P., Conte V., Hanani M. Systemic
During last two years on published articles in magazines "Science" [Kayagaki N. et al., 2013; Hagar J.A. et al., 2013] and "Nature" [Shi J. et al., 2014] was approved cause to death of cell by pyrosytosis with modern methods used in the molecular biology, that entered into cytosol LPS connected directly with caspase-11 (its homologue in humanis caspase-4), without TLR4. So, it is possible to consider from the conclusion of this study work that, the death of spinal ganglia macrophages via pyroptosis due the direct connection of caspase with LPS as the electron microscopic confirmation.

Conslusion. The main peculiarity pseudounipolar neurons of spinal ganglia from other part of nervous system that their wholly coverage with satellite glial cell. It is interesting that the expression of TLR4, receiving the LPS signals both in vitro and in vivo conditions, occur not in glial cells, it's in pseudouipolar neurons, the Tse K.H. et al. (2014a) offer to estimate it as prevention method of uncontrolled inflammatory process in spinal ganglion. At endotoxemia the interruption of tight junction between glial cells and pseudounipolar neurons [Tse K.H et al., 2014b] results in expression of TLR4 in first one. The analysis of acquired information shows that, pseudounipolar neurons is subjected to irreversible degenerative changes in the result of their losing connection with satellite glia cells composing the preventive covers of their immune system due pressure of edema fluid.

\section{This work is implemented basing on financial} support of the Science Development Foundation under the President of the Republic of Azerbaijan. Grant № EIF-2011-1(3)-82/44/3-M-6.

inflammation alters satellite glial cell function and structure. A possible contribution to pain // Neuroscience. 2014, 274, pp.209-17.

4. Chuang Y.C., Lei H.Y., Liu H.S. et al. Macrophage migration inhibitory factor induced by dengue virus infection increases vascular permeability // Cytokine, 2011, 54(2), pp.222-231.

5. Cookson B.T., Brennan M.A. Pro-inflammatory programmed cell death // Trends in Microbiology, 2001, Vol. 9, Issue 3, pp.113-114 
6. Electron Microscopy. Methods and Protocols. / Edited by John Kuo. USA, Totowa, New Jersey: Humana Press Inc., 2007, 608 p.

7. Fink S.L., Cookson B.T. Pyroptosis and host cell death responses during Salmonella infection // Cell Microbiol., 2007, 9(11), pp.2562-70.

8. Fujihara M., Muroi M., Tanamoto K., Suzuki T., Azuma H., Ikeda H. Molecular mechanisms of macrophage activation and deactivation by lipopolysaccharide: roles of the receptor complex // Pharmacol Ther., 2003, 100(2), pp.171-94.

9. Hagar J.A., Powell D.A., Aachoui Y., Ernst R.K., Miao E.A. Cytoplasmic LPS activates caspase-11: implications in TLR4-independent endotoxic shock // Science., 2013, 341(6151), pp.1250-3.

10. Hanani M. Intercellular communication in sensory ganglia by purinergic receptors and gap junctions: implications for chronic pain // Brain Res. 2012, v.3, No 1487, p.183-91

11. Kang S., Lee S.P., Kim K.E., Kim H.Z., Memet S., Koh G.Y. Toll-like receptor 4 in lymphatic endothelial cells contributes to LPS-induced lymphangiogenesis by chemotactic recruitment of macrophages // 2009, 113(11), pp.2605-13.

12. Kayagaki N., Wong M.T., Stowe I.B., Ramani S.R., Gonzalez L.C., Akashi-Takamura S., Miyake K., Zhang J., Lee W.P., Muszynski A., Forsberg L.S., Carlson R.W., Dixit V.M. Noncanonical inflammasome activation by intracellular LPS independent of TLR4 // Science., 2013, 341(6151), pp.1246-9.

13. Li Y., Ji A., Weihe E., SchËafer M. K. Cell-Specific Expression and Lipopolysaccharide-Induced Regulation of Tumor Necrosis Factor $\alpha(\operatorname{tnf} \alpha)$ and TNF Receptors in Rat Dorsal Root Ganglion // The Journal of Neuroscience, 2004, 24(43), pp.9623-9631

14. Liu F.Y., Sun Y.N., Wang F.T., Li Q. et all Activation of satellite glial cells in lumbar dorsal root ganglia contributes to neuropathic pain after spinal nerve ligation // Brain Res. 2012, v.1427, p.65-77.

15. McKay H.A., Brannstrom T., Wiberg M., Terenghi G. Primary sensory neurons and satellite cells after peripheral axotomy in the adult rat: timecourse of cell death and elimination // Exp Brain Res., 2002, 142(3), pp.308-18.

16. Medzhitov R., and Janeway C., Jr.. The Toll receptor family and microbial recognition // Trends Microbiol., 2000, 8, pp.452-456.

17. Miao E.A., Rajan J.V., Aderem A. Caspase-1-induced pyroptotic cell death // Immunol Rev., 2011, 243(1), pp.206-14.

18. Momeni H.R, Soleimani M. M., Shariatzadeh M.A., Haddadi M. Caspase-mediated apoptosis in sensory neurons of cultured dorsal root Ganglia in adult mous // Cell J., 2013, 15(3), pp.212-7.

19. Ng K.Y., Yeung B.H., Wong Y.H., Wise H. Isolated dorsal root ganglion neurones inhibit receptor-dependent adenylyl cyclase activity in associated glial cells // $\mathrm{Br} \mathbf{J}$ Pharmacol., 2013, 168(3), pp.746-60

20. Pannese E. The structure of the perineuronal sheath of satellite glial cells (SGCs) in sensory ganglia // Neuron Glia Biology, 2010, v.6, No 1, p.3-10

21. Prins B.A., Hu R.M., Nazario B., Pedram A., Frank H.J., Weber M.A., Levin E.R. Prostaglandin E2 and prostacyclin inhibit the production and secretion of endothelin from cultured endothelial cells // J Biol Chem., 1994, 269(16), pp.11938-44.

22. Qu Y., Misaghi S., Izrael-Tomasevic A., Newton K., Gilmour L.L., Lamkanfi M., Louie S., Kayagaki N., Liu J., Kömüves L., Cupp J.E., Arnott D., Monack D., Dixit V.M. Phosphorylation of NLRC4 is critical for inflammasome activation // Nature, 2012, 490(7421), pp.539-42.

23. Ramesh G., Santana-Gould L., Inglis F.M., England J.D., Philipp M.T. The Lyme disease spirochete Borrelia burgdorferi induces inflammation and apoptosis in cells from dorsal root ganglia // J Neuroinflammation. 2013, 10, pp.88. 24. Roger T., Froidevaux C., Martin C., Calandra T. Macrophage migration inhibitory factor (MIF) regulates host responses to endotoxin through modulation of Toll-like receptor 4 (TLR4) // J Endotoxin Res., 2003, 9(2), pp.119-123.

25. Shi J., Zhao Y., Wang Y., Gao W., Ding J., Li P., Hu L., Shao F. Inflammatory caspases are innate immune receptors for intracellular LPS // Nature, 2014, 514(7521), pp.187-92.

26. Tomiwa K., Nolan C., Cavanagh J.B. The effects of cisplatin on rat spinal ganglia: a study by light and electron microscopy and by morphometry // Acta Neuropathol., 1986, 69(3-4), pp. 295-308.

27. Tse K.H., Chow K.B., Leung W.K., Wong Y.H., Wise H. Lipopolysaccharide differentially modulates expression of cytokines and cyclooxygenases in dorsal root ganglion cells via Toll-like receptor-4 dependent pathways // Neuroscience, 2014, 267, pp.241-51

28. Tse K.H., Chow K.B., Leung W.K., Wong Y.H., Wise H. Primary sensory neurons regulate Toll-like receptor-4dependent activity of glial cells in dorsal root ganglia // Neuroscience, 2014, 279, pp.10-22.

29. Zhou H., Andonegui G., Wong C.H., Kubes P. Role of endothelial TLR4 for neutrophil recruitment into central nervous system microvessels in systemic inflammation // J Immunol., 2009, 183(8), pp.5244-50.

30. Oliyarbəyova A.Ә., Qasımov E.K. A ğ siçovulların onurğa beyni qanqlionunda neyroqlial əlaqələrin mikroskopik və ultrastruktur xüsusiyyətləri. Azərbaycan Tibb Jurnalı ATJ, 2014, №2, s.32-39.

31. Qasımov E.K., Okbərov E.Ç., Quliyeva N.T., Әyyubova G.M., Nəcəfova T.M., Oliyarbəyova A.Ө. Perinevral qişanın təşkilində iştirak edən strukturların histoloji və ultrastruktur quruluş xüsusiyyətləri // Azərbaycan Tibb Jurnal1, 2009, № 4, s.52-57.

32. Qasımov E.K., Quliyeva N.T., Әyyubova G.M., Okbərov E.Ç. Eksperimental ödem şəraitində oturaq sinirinin perinevral qişasının histoloji və elektron mikroskopik quruluş xüsusiyyətləri // Azərbaycan Tibb Jurnal1, 2010, № 2, s.88-92.

33. Qasımov E.K., Oliyarbəyova A.Ө. A $\breve{g}$ siçovullarda onurğa beyni qanqlionunun sito - və mielo arxitektonikasinin işıq və elektron mikroskopik tədqiqi. Azərbaycan Tibb Jurnal1, 2013, №3, s.43-51. 


\title{
XÜLASə
}

\section{KəSKIN EKSPERIMENTAL ÖDEM ZAMANI ONURĞA BEYNI QANQLIONLARININ QISSAA-DAMAR-QLIYYA-SINIIR ELEMENTLӘRINDヨ BAŞ VERӘN STRUKTUR DəYIŞSIKLIKLӘR. ISSIQ Və ELEKTRON MIKROSKOPIK TODQIQAT.}

\author{
Qasımov E.K., Oliyarbəyova A.ə. \\ Azərbaycan Tibb Universitetinin Histologiya, embriologiya və sitologiya kafedrasl, Bakl
}

Venadaxilinə yeridilmiş endotoksinin (LPS) damar keçiriciliyini artırması nəticəsində OBQ-nin subkapsulyar, perivaskulyar, perineyronal və intraneyronal sahələrində ödem mayesinin yerləşməsinə məxsus rənglənməmiş sahələr aşkar edilmişdir. Ödem mayesinin mexaniki təsirindən OBQ kapsulunun daxili qatında formalaşan "perinevral pəncərələr"in ölçüləri OBQ damarları sayından və onların perimetrlərindən (mübadilə səthindən) asılıdır. Peyk qliya hüceyrə ilə yalançı unipolyar sinir hüceyrəsi arasında əlaqələrin pozulması degenerativ tünd neyronların formalaşması ilə nəticələnir. Bağırsaq çöpü (E.coli) bakteriyalarının özlərinin yox, onların divarının təşkilində iştirak edən LPS-in OBQ daxili makrofaqların piroptoz yolu ilə ölümünə səbəb olmaları ultrastruktur olaraq təsdiq edilmişdir.

Açar sözlər: onurğa beyni qanqlionu, kəskin endotoksemiya, degenerativ neyron, piroptoz, transmission elektron mikroskopiya.

\section{РЕЗЮМЕ}

\section{СТРУКТУРНЫЕ ИЗМЕНЕНИЯ ОБОЛОЧЕК, СОСУДИСТЫХ, ГЛИАЛЬНЫХ И НЕРВНЫХ ЭЛЕМЕНТОВ СПИНАЛЬНЫХ ГАНГЛИЙ ПРИ ОСТРОМ ЭКСПЕРИМЕНТАЛЬНОМ ОТЁКЕ. СВЕТОВОЕ И ЭЛЕКТРОННО- МИКРОСКОПИЧЕСКОЕ ИССЛЕДОВАНИЯ.}

\author{
Гасымов Э.К., Алиярбекова А.А. \\ Кафедра ичитологии, эмбриологии и гистологии Азербайджанского Медицинского \\ Университета, Баку
}

В результате повышения сосудистой проницаемости под воздействием внутривенно введенного эндотоксина (ЛПС) в субкапсулярном, периваскулярном, перинейрональном и интернейрональных пространствах спинальных ганглиев были выявлены неокрашенные участки, соответствующие расположению отёчной жидкости. Размеры "периневральных окон", формирующихся во внутреннем слое капсулы спинального ганглиона зависит от количества и периметра (площади обменной поверхности) сосудов спинальных ганглиев. Нарушение взаимоотношений между псевдоуниполярными нейронами и глиальными сателлитными клетками приводит к образованию тёмных дегенеративных нейронов. Ультраструктурно было доказано, что причиной пироптозной гибели макрофагов, находящихся внутри спинальных ганглиев является не сама кишечная палочка, а ЛПС, входящий в состав его стенки. Ключевые слова: спинальный ганглион, острая эндотоксемия, пироптоз, дегенеративный нейрон, трансмиссионый электронный микроскоп.

Redaksiyaya daxil olub: 10.12.2014

Çapa tövsiya olunub: 07.01.2015

Rəyçi: t.e.d., prof. R.K.Şiraliyeva 